\title{
Late Holocene climate and environmental changes in Kamchatka inferred from the subfossil chironomid record
}

\author{
Larisa Nazarova ${ }^{\mathrm{a}, \mathrm{b}, *}$, Verena de $\operatorname{Hoog}^{\mathrm{c}}$, Ulrike Hoff ${ }^{\mathrm{d}}$, Oleg Dirksen ${ }^{\mathrm{e}}$, Bernhard Diekmann ${ }^{\mathrm{a}}$ \\ a Alfred Wegener Institute for Polar and Marine Research, Research Unit Potsdam, Telegrafenberg A43, 14473 Potsdam, Germany \\ ${ }^{\mathrm{b}}$ Kazan Federal University, Kremlyovskaya Str., 18, 420018 Kazan, Russia \\ ${ }^{c}$ Potsdam University, Am Neuen Palais 10, 14469 Potsdam, Germany \\ ${ }^{\mathrm{d}}$ University of Tromsø, Department of Geology, Dramsveien 201, 9037 Tromsø, Norway \\ e Institute of Volcanology and Seismology FED RAS, Piipa blvd., 9, 683006 Petropavlovsk-Kamchatsky, Russia
}

\section{A R T I C L E I N F O}

\section{Article history:}

Received 24 October 2012

Received in revised form

16 January 2013

Accepted 19 January 2013

Available online

\section{Keywords:}

Kamchatka

Holocene

Chironomids

Palaeoclimate

Temperature

\begin{abstract}
A B S T R A C T
This study presents a reconstruction of the Late Holocene climate in Kamchatka based on chironomid remains from a $332 \mathrm{~cm}$ long composite sediment core recovered from Dvuyurtochnoe Lake (Two-Yurts Lake, TYL) in central Kamchatka. The oldest recovered sediments date to about 4500 cal years BP. Chironomid head capsules from TYL reflect a rich and diverse fauna. An unknown morphotype of Tanytarsini, Tanytarsus type klein, was found in the lake sediments. Our analysis reveals four chironomid assemblage zones reflecting four different climatic periods in the Late Holocene. Between 4500 and 4000 cal years BP, the chironomid composition indicates a high lake level, well-oxygenated lake water conditions and close to modern temperatures $\left(\sim 13^{\circ} \mathrm{C}\right)$. From 4000 to 1000 cal years BP, two consecutive warm intervals were recorded, with the highest reconstructed temperature reaching $16.8{ }^{\circ} \mathrm{C}$ between 3700 and $2800 \mathrm{cal}$ years BP. Cooling trend, started around $1100 \mathrm{cal}$ years BP led to low temperatures during the last stage of the Holocene. Comparison with other regional studies has shown that termination of cooling at the beginning of late Holocene is relatively synchronous in central Kamchatka, South Kurile, Bering and Japanese Islands and take place around 3700 cal years BP. From ca 3700 cal years BP to the last millennium, a newly strengthened climate continentality accompanied by general warming trend with minor cool excursions led to apparent spatial heterogeneity of climatic patterns in the region. Some timing differences in climatic changes reconstructed from chironomid record of TYL sediments and late Holocene events reconstructed from other sites and other proxies might be linked to differences in local forcing mechanisms or caused by the different degree of dating precision, the different temporal resolution, and the different sensitive responses of climate proxies to the climate variations. Further high-resolution stratigraphic studies in this region are needed to understand the spatially complex pattern of climate change in Holocene in Kamchatka and the surrounding region.
\end{abstract}

(c) 2013 Elsevier Ltd. All rights reserved.

\section{Introduction}

The Kamchatka Peninsula shapes the eastern edge of Siberia and separates the Sea of Okhotsk from the Pacific Ocean. It is one of the least studied regions in Eurasia. The climate history of the last 400 years in Kamchatka is well documented in tree-ring and ice-core records and suggests short-term climate oscillations at centennial

\footnotetext{
* Corresponding author. Alfred Wegener Institute for Polar and Marine Research, Research Unit Potsdam, Telegrafenberg A43, 14473 Potsdam, Germany. Tel.: +49 331 2882210; fax: +493312882137.

E-mail addresses: larisa.nazarova@awi.de, nazarova_larisa@mail.ru (L. Nazarova).
}

to decadal time scales (Solomina et al., 2007; Sano et al., 2009, 2010). Less is known about the Holocene environmental dynamics in the region (Pisaric et al., 2001; Razjigaeva et al., 2004; Fradkina et al., 2005; Kokorowski et al., 2008).

Studies of the Holocene climate in Kamchatka are limited and mainly focus on reconstruction of vegetation dynamics from pollen records in peat sections (Dirksen and Uspenskaya, 2005; Dirksen and Dirksen, 2008) or reconstructions of glacial dynamics in southern and central Kamchatka (Zech et al., 1997; Savoskul, 1999). The present study is focussed on qualitative and quantitative reconstructions of environmental changes using chironomids, which have proven to be useful indicators of environmental variations (Battarbee, 2000; Smol et al., 2005; Stief et al., 2005; Kienast et al., 2011; Self et al., 2011). Past climate can be quantified from fossil 
chironomid assemblages by using inference models (Larocque et al., 2001; Solovieva et al., 2005; Barley et al., 2006; Nazarova, 2012; Nazarova et al., in press), which link the present distribution and abundance of chironomids to contemporary climate. The main objective of our study is to perform a palaeoecological reconstruction of the late Quaternary climate and environment in Kamchatka from sediments of Dvuyurtochnoe Lake (Two-Yurts Lake, TYL), situated in Central Kamchatka. The specific aim is to provide reconstructions of mean July air temperature $\left(T_{\text {July }}\right)$, using the newly developed for north-eastern Russia chironomid-inferred mean July temperature model (Nazarova et al., 2011).

\section{Study area}

The Kamchatka is a peninsula in the Russian Far East that lies between the Pacific Ocean to the east and the Sea of Okhotsk to the west (Fig. 1). The longitudinal extent of the peninsula is approximately $1600 \mathrm{~km}$ and the maximum width is $500 \mathrm{~km}$ (Nazarova,

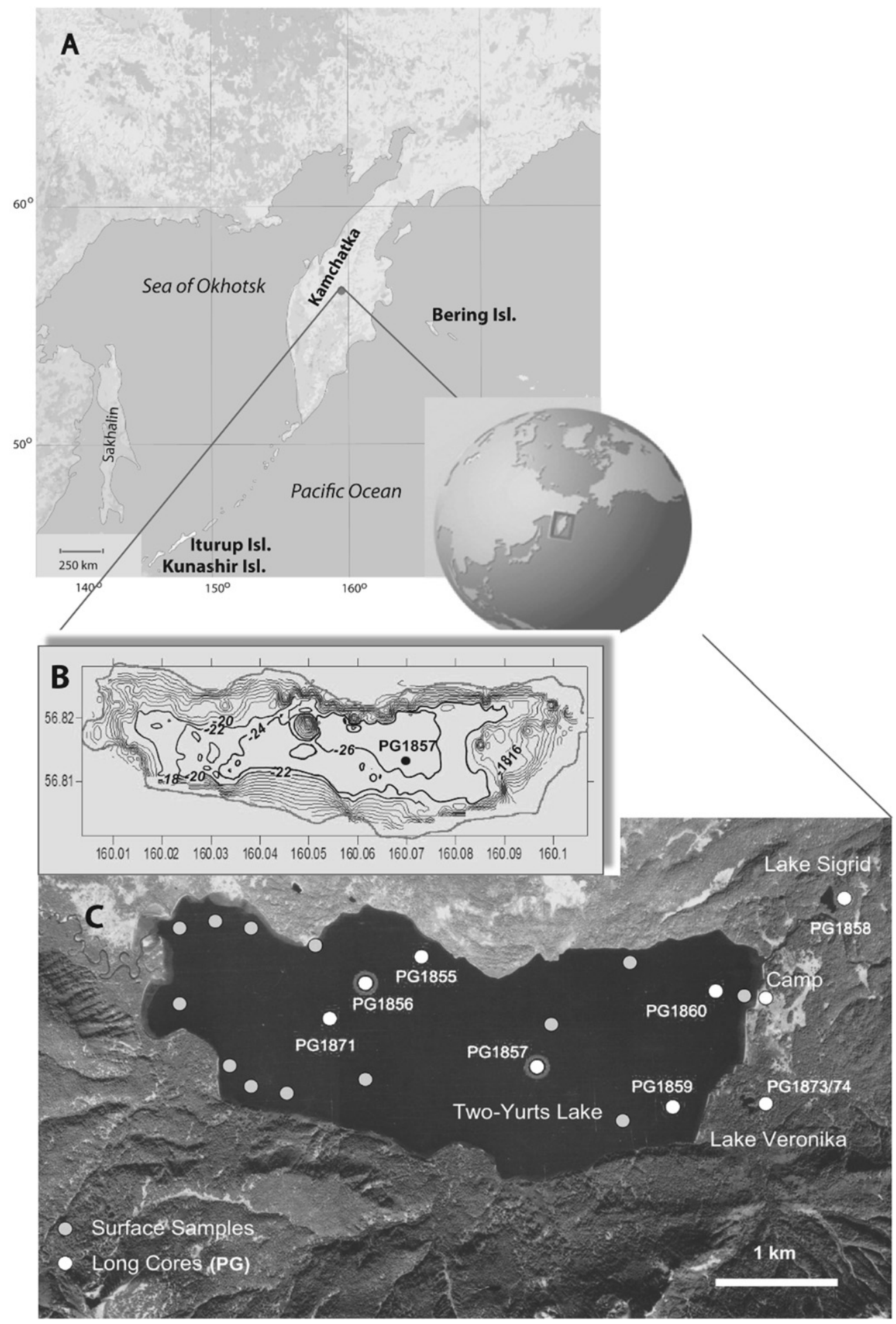

Fig. 1. A. Map of the region and location of the TYL in Kamchatka; B. Bathymetric map of TYL; C. Position of the sampling sites. 
1999). Active volcanoes are part of the two mountain systems of the Kamchatka Peninsula: the Sredinny and the Vostochny mountain ranges. The Central Kamchatka Lowland is situated between the two mountain ranges and consists of alluvial, lacustrine and fluvioglacial deposits (Shiraiwa and Tchoumitchev, 2002). The geographic position, surrounding sea, Pacific Ocean and the relief are all factors forming diverse and variable weather in Kamchatka. The orientation of the mountain ranges protects the inner regions of the peninsula from the influence of the North Pacific, leading to a more continental climate in the interior. Mean annual temperature ranges from $-2{ }^{\circ} \mathrm{C}$ to $-3{ }^{\circ} \mathrm{C}$. The highest monthly mean (July) ranges from 12 to $16{ }^{\circ} \mathrm{C}$ and the lowest monthly mean (January) ranges from $-18{ }^{\circ} \mathrm{C}$ to $-20{ }^{\circ} \mathrm{C}$ (New et al., 2002). Annual precipitation in the Central Valley is $350 \mathrm{~mm}$ (Krestov et al., 2008; Neshataeva, 2008).

The Kamchatka Peninsula belongs to the maritime and suboceanic sectors of the boreal zone. High humidity, relatively low temperatures, short growing seasons and heavy snowfalls create unique ecological conditions, known as snow forests (Krestov et al., 2008), ideally suited for dwarf alder (Alnus fruticosa), dwarf pine (Pinus pumila) and Ermann's birch (Betula ermanii) forests. The continental climatic conditions in the Central Kamchatka depression support isolated populations of Larix cajanderi, Picea ajanensis and Betula platyphylla, which form forests at lower elevations (Krestov et al., 2008; Neshataeva, 2008).

TYL $\left(56^{\circ} 49,2^{\prime} \mathrm{N} ; 160^{\circ} 06,3^{\prime} \mathrm{E}\right)$ is a freshwater lake in the northcentral part of the Kamchatka peninsula (Fig. 1). It is located in the inter-mountain depression at the eastern slope of Sredinny Ridge, the largest watershed in Kamchatka, stretching more than $700 \mathrm{~km}$ along the peninsula axis. Mean July air temperature at the lake location is approximately $13{ }^{\circ} \mathrm{C}$ (New et al., 2002). The mean water depth of this open through-flow lake system is between 21 and $27 \mathrm{~m}$. The lake has an area of $12 \mathrm{~km}^{2}$ and a maximum depth of ca $25 \mathrm{~m}$ (Dirksen et al., 2011). TYL has an extension of $\sim 5 \times 2 \mathrm{~km}$ at an elevation of $280 \mathrm{~m}$ above sea-level (a.s.l.). The lake water has neutral $\mathrm{pH}$, is meso-oligotrophic and has a slight oxygen undersaturation in summer (Hoff, 2010). Water profiles show dilute freshwater conditions with extremely low salinity (total dissolved ions: $40-44 \mathrm{mg} / \mathrm{L}$, conductivity: $\pm 54 \mu \mathrm{S} / \mathrm{cm}$ ) and ion composition with $\mathrm{Na}^{+} \gg \mathrm{Ca}^{2+} \gg \mathrm{Mg}^{2+} \geq \mathrm{K}^{+}$, and $\mathrm{HCO}_{3}^{-} \gg \mathrm{SO}_{4}^{2-} \geq \mathrm{Cl}^{-}$(Hoff, 2010), pointing to waters supplied by river runoff and precipitation (Wetzel, 2001). High silica (Si) concentration ( $\geq 6.0 \mathrm{mg} / \mathrm{l}$ ) reflects the wide distribution of volcanic rocks and soils in the catchment, which are prone to leaching. The water isotopic composition is relatively constant with $-14.8 \%$ for $\delta{ }^{18} \mathrm{O}$ and between $-107.5 \%$ and $-110.9 \%$ for $\delta \mathrm{D}$. The data are well aligned on the Global Meteoric Water Line (GMWL), suggesting the absence of any evaporation effects on the isotopic composition (Hoff, 2010). The water profile of Two-Yurts Lake does not show significant variations in temperature with depth, indicating that the lake was well mixed in late summer 2007. If any summer water stratification was present at all, it came to nothing during the stormy days during the field stay. Total organic carbon values in the sediments (TOC) show reasonably stable and low values (mean $1.6 \mathrm{wt}$ \%) throughout the core. Small TOC drops occur near the ash layers, possibly related to the contamination of pure lake sediments with ash particles. The carbon to nitrogen ratio $(\mathrm{C} / \mathrm{N})$ remains at low values around 4 throughout the core, pointing to an algae dominated system (Hoff, 2010).

There are three inflows from the west and one outflow at the east, the Dvuh-Yurtochnaya River. This river travels $75 \mathrm{~km}$ and flows into the Kamchatka River, the largest river on the peninsula. High volcanic activity in this area during the Late Pliocene - Early Pleistocene deposited strata, with Late Pliocene - Early Quaternary pyroclastic deposits armoured with a thick package of Early
Pleistocene lava flows, building a subhorizontal, plateau-like surface (Dirksen et al., 2011). This surface was later disrupted by intense faulting in the Middle-Late Pleistocene. During the Late Pleistocene, Sredinny Ridge was one of the main sources for glaciation in Kamchatka (Bigg et al., 2008). The glaciers eroded most of the inter-mountain depressions and created valleys oriented NWSE. Thick LGM glaciers spread along Two-Yurts valley and deposited two end moraines $20 \mathrm{~km}$ downstream of the lake. Excluding the shallow parts at the inflows, the steep embankments merge into steep, subaquatic slopes. East and west shores are steep without littoral. South shore has $40 \mathrm{~m}$ bright sandy littoral zone, north shore has $20 \mathrm{~m}$ bright littoral zone with small amount of submerged vegetation.

A Dvuh-Yurtochnaya thermal system is situated at the west side of the lake, north of the Dvuh-Yurtochnaya River. The system consists of central, northern, western and eastern groups of springs (Andreeva et al., 2008). Only the western group is directly connected to the Dvuh-Yurtochnaya River. The springs of the western group are situated $150 \mathrm{~m}$ north of the left channel of the river and $\sim 2 \mathrm{~km}$ west of the TYL. Thermal springs first form a $1.5 \mathrm{~m}$ diameter thermal pond. The pond is connected with the river by a small, strongly meandering brook. The hydrological debit of the brook on the spring's side is $3 \mathrm{l} / \mathrm{s}$ (Lodis and Semenov, 1993; Andreeva et al., 2008). Considering the low volume of outflowing water and long travel distance of hot water from the thermal pond to TYL, we assume that there is no significant thermal influence of the hot springs on the hydrobiological system of the TYL.

\section{Methods}

\subsection{Field work}

The TYL was sampled in September 2007. Water depth (WD) was measured using a Garmin-Fishfinder-system echolot with a vertical resolution of ca $10 \mathrm{~cm}$. Echographic surveying was conducted using a GEOPULSE Shallow Seismic 3.5-kHz-Profiler System to locate stations for sediment coring.

TYL sediment cores were obtained with a tripod-supported UWITEC piston corer from a floating platform at different locations in the lake. Two cores (1857-2 - upper core and 1857-5 lower core) consisted of diatom-rich oozes with a soupy consistency. These cores were collected from site 1857, situated in the central part of the lake, at a depth of approximately $25 \mathrm{~m}$ (Fig. 1), within an area of gentle hummocky bottom topography.

During the successive penetrations of the corer into the sediments, the piston of the corer was fixed every $250 \mathrm{~cm}$, on average, to obtain sediment cores with sufficient overlap. The sediment cores were split into two to three $\mathrm{cm}$ subsamples and freeze-dried for micropaleontological, sedimentological and stratigraphic studies at AWI Potsdam. The detailed sedimentological characteristics of the cores are described in Hoff (2010) and Dirksen et al. (2011) and will be presented elsewhere.

The two sediment cores (1857-2 and 1857-5) together provided a $332 \mathrm{~cm}$ long composite section. Criteria for splicing were based on changes in sand concentration, diatom abundances, appearance of distinct ash layers and radiocarbon data (Hoff, 2010; Dirksen et al., 2011). The composite core consisted of the upper $180 \mathrm{~cm}$ of core $1857-2$ (layers $2 \mathrm{~cm}-181 \mathrm{~cm}$ ) and a $150 \mathrm{~cm}$ section of core 1857-5 $(59-211 \mathrm{~cm})$. Sedimentological data with tephra layers and $\mathrm{C}^{14}$ dates are presented in Dirksen et al. (2011).

\subsection{Dating}

Two different methods were chosen to develop an age model for the sediment record. First, radiocarbon $\left({ }^{14} \mathrm{C}\right)$ AMS Accelerator Mass 
Spectrometry dating lake gyttia from lacustrine cores was conducted on 12 samples (Dirksen et al., 2011) and on three additional samples in 2011 at the Poznan Radiocarbon Laboratory, Poland (Table 1). Radiocarbon measurements were subsequently converted into calendar ages $\mathrm{BC} / \mathrm{AD}(0 \mathrm{cal}$. $\mathrm{BP}=\mathrm{AD} 1950)$ using the CalPal Online program (Danzeglock et al., 2010). Second, sixteen volcanic tephra layers were analysed for mineralogy at the Kyoto Fission Track Co. The major element compositions of glasses were analysed with a JEOL JSM-5800LV attached JEOL superminicup semiconductor detector and Oxford Link ISIS EDX at the University of Fukushima. The chemical composition of glass shards from the lake core tephras was analysed with a JEOL electron microprobe at IFM-GEOMAR, Kiel (Dirksen et al., 2011).

Both dating techniques provide acceptable age constraints with increasing down-core ages in the composite sediment record. Nine and seven tephra layers were discovered in cores PG1857-2 and PG1857-5, respectively. These records were spliced together and correlated (Dirksen et al., 2011, Figs. 7 and 10). The upper sediment core PG1857-2 was spliced at $167 \mathrm{~cm}$ core depth with sediment core PG1857-5 at $70 \mathrm{~cm}$ core depth, where both records, within the 2-sigma error range, revealed almost identical ages (2551/2574 cal years BP, Table 1$)$. The age model was constructed using a conservative approach by linear interpolation between respective radiocarbon ages. Apart from the interval between 92 and $123 \mathrm{~cm}$, sedimentation rate remained quite constant (0.5-0.8 mm/year). The uniform lithological composition of the core with a dominance of diatoms in the sediments is consistent with a stable depositional environment. The origin of the volcanic ash layers (tephra) has been described in detail by Dirksen et al. (2011).

Significant inconsistency between the age of the tephras and radiocarbon dating and the presence of younger tephras in the lower core, compared to the lowermost tephra found in the upper core called the tephra identification into question. Most of the tephras are significantly deeper than contemporaneous lacustrine deposits. The possibility of constant error in radiocarbon dating is excluded, because results yielded very appropriate dates for terrestrial deposits sampled from the TYL shore area as well as for lake deposits in Sigrid Lake, which is located just a few meters from TYL. A plausible explanation for the discrepancy could be penetration of tephra particles through the lake sediment because neither visual inspection nor instrumental investigations reveal any disturbance or sharp changes in deposit characteristics within the inspected interval. Moreover, the results of radiocarbon dating did not reveal any reservoir effect (Dirksen et al., 2011, Fig. 7). The soupy consistency of the lacustrine deposits could facilitate tephra sinking during or just after deposition. Additionally, most of the tephras demonstrate a depth of submergence of the same order of magnitude, $60-100 \mathrm{~cm}$, also supporting the idea of sinking. Similar submergence of distal tephras with greater age amplitude was reported by Beierle and Bond (2002) in the Copper and Doal lakes,

\section{Table 1}

AMS ${ }^{14} \mathrm{C}$ dates for Two-Yurts Lake.

\begin{tabular}{lccrc}
\hline Sample code & Core & $\begin{array}{l}\text { Composite core } \\
\text { depth }(\mathrm{cm})\end{array}$ & $\begin{array}{l}\text { Age }\left({ }^{14} \mathrm{C}\right. \\
\text { years BP })\end{array}$ & $\begin{array}{l}\text { Age (cal } \\
\text { years BP) }\end{array}$ \\
\hline Poz-31549 & $1857-2$ & 6 & $110 \pm 30$ & $142 \pm 97$ \\
Poz-36399 & $1857-2$ & 70 & $1375 \pm 35$ & $1304 \pm 17$ \\
Poz-42178 $^{\text {a }}$ & $1857-2$ & 92 & $1810 \pm 40$ & $1754 \pm 50$ \\
Poz-42179 $^{\text {a }}$ & $1857-2$ & 123 & $1880 \pm 40$ & $1815 \pm 54$ \\
Poz-36401 $^{\text {a }}$ & $1857-2$ & 167 & $2460 \pm 35$ & $2551 \pm 117$ \\
Poz-36400 & $1857-5$ & 70 & $2475 \pm 35$ & $2574 \pm 100$ \\
Poz-29022 & $1857-5$ & 226 & $3250 \pm 35$ & $3484 \pm 54$ \\
Poz-31550 & $1857-5$ & 257 & $3660 \pm 35$ & $3999 \pm 64$ \\
Poz-31551 & $1857-5$ & 297 & $3980 \pm 40$ & $4465 \pm 43$ \\
\hline
\end{tabular}

a Samples analysed in 2011.
Canada, or was described for the Laacher-See in southern Germany (Lotter and Hölzer, 1989).

For these reasons, the age model used in our investigation is based solely on the radiocarbon stratigraphy of the composite sediment core PG1857 (Table 1, Fig. 2).

\subsection{Chironomid analysis}

Chironomid analysis was conducted at $5-10 \mathrm{~cm}$ resolution. In total, 51 samples were investigated (27 samples from core 1857-2 and 24 samples from core 1857-5). Fifteen samples were later excluded from the analysis, 8 samples from core 1857-2 and 7 samples from 1857-5, when dating and further splicing showed a pronounced overlap constituting a $70 \mathrm{~cm}$ section of core 1857-2 and a $60 \mathrm{~cm}$ section of core 1857-5.

Treatment of sediment samples for chironomid analysis followed standard techniques described in Brooks and Birks (2000). Subsamples of wet sediments were deflocculated in $10 \% \mathrm{KOH}$, heated to $70^{\circ} \mathrm{C}$ for up to $10 \mathrm{~min}$ by adding boiling water and left for another $20 \mathrm{~min}$. The sediment was then passed through stacked 225 and $90 \mu \mathrm{m}$ sieves. Chironomid larval head capsules were picked out of a grooved Bogorov sorting tray using fine forceps under a stereomicroscope at $25-40 \times$ magnification. To capture the maximum diversity of the chironomid population, 50-147 chironomid larval head capsules were extracted from each sample. Several studies have demonstrated that this sample size is adequate for a reliable estimate of inferred temperature (Larocque, 2001; Quinlan and Smol, 2001). Larval head capsules were mounted two at a time in Euparal or Hydromatrix, ventral side up, under a $6 \mathrm{~mm}$ diameter cover slip, with ten cover slips per microscope slide. In total, 3753 chironomid head capsules were slide mounted and identified. Chironomids were identified to the highest taxonomic resolution possible with reference to Wiederholm (1983) and Brooks et al. (2007).

Due to the large regional variations in the temperature optima of each taxon, there is no general classification for dividing chironomids into warm-adapted and cold-adapted taxa. For our discussion, we accepted the following classification of the chironomid taxa on the basis of their mean July air temperature ( $\left.T_{\text {July }}\right)$ optima, calculated from the modern Yakutian data set (Nazarova et al., 2008, 2011): cold-adapted taxa with $T_{\text {July }}$ optima $\leq 12{ }^{\circ} \mathrm{C}$, temperate-

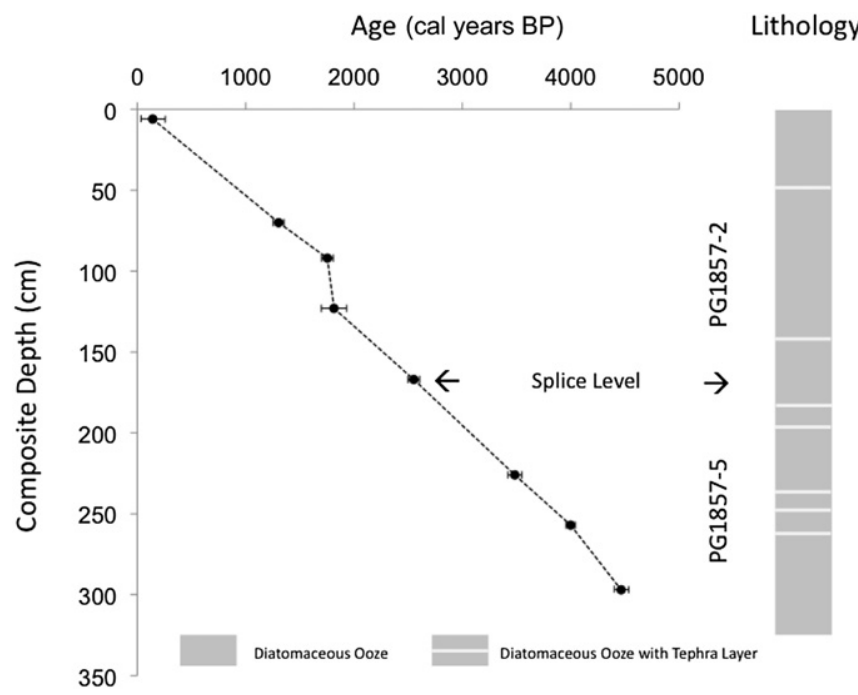

Fig. 2. Age-depth relationship of composite sediment sequence PG1857 of TYL. Dates are based on AMS radiocarbon analysis of bulk sediments. Error bars show two-sigma error range of age dates. 
adapted taxa with $T_{\text {July }}$ optima $\geq 12$ and $\leq 14{ }^{\circ} \mathrm{C}$ and warm-adapted taxa with $T_{\text {July }}$ optima $\geq 14{ }^{\circ} \mathrm{C}$.

\subsection{Data analysis}

A chironomid-percentage stratigraphic diagram was made in C2 version 1.5 (Juggins, 2007) (Fig. 3). Zonation of the chironomid stratigraphy was accomplished using the optimal sum-of-squares partitioning method (Birks and Gordon, 1985) using the ZONE program (Lotter and Juggins, 1991), where the number of significant zones was assessed by a broken stick model (Bennett, 1996) using BSTICK (Birks and Line unpublished). Effective numbers of occurrences of chironomid taxa were estimated using the N2 index (Hill, 1973). Detrended Correspondence Analysis (DCA) was performed to examine trends within the chironomid data and determine whether linear or unimodal based numerical techniques should be used. DCA and PCA were performed using CANOCO 4.5 (ter Braak and Šmilauer, 2002). Chironomid abundance data were square-root-transformed.

Mean July air temperatures $\left(T_{\text {July }}\right)$ were reconstructed using a modern chironomid-based temperature calibration data set (training set) from Yakutia, North-Eastern Russia (Nazarova et al., 2008, 2011). The $T_{\text {July }}$ training set contains 143 lakes spanning a temperature gradient from 3.4 to $18.8^{\circ} \mathrm{C}$. The two-component $T_{\text {July }}$ weighted average - partial least square model (WA-PLS) had the best performance; the coefficient of determination $r^{2}$ boot $=0.87$, root mean square error of prediction $($ RMSEP) $=1.93$. Sample- specific estimated standard errors (eSEPs) were estimated through bootstrapping ( 100 cycles) using $\mathrm{C} 2$. The percentage abundances of the fossil chironomids that are absent or rare in the modern Yakutian calibration data set (Engels et al., 2010) were calculated. A taxon is considered to be rare in the modern data when it has a Hill's N2 (Hill, 1973) below 5. Optima of taxa that are rare in the modern data are likely to be poorly estimated (Brooks and Birks, 2001).

A principal components analysis (PCA) was performed to evaluate the reconstructed palaeotemperatures. The sample scores of the first few PC axes were compared to the reconstructed temperatures. The variability of the sample scores is, at least theoretically, determined by the first few ecological gradients of the species. Ideally, it should be dominated mainly by the variable being reconstructed (Kumke et al., 2004).

In order to further explore the relationship between training set analogues and the TYL subfossil sequence the data were combined and analysed using a 'time-track' CCA with the TYL samples plotted passively. To determine whether the modern calibration models had adequate analogues for the fossil assemblages, the modern analogue technique (MAT) was performed using C2 version 1.5 (Juggins, 2007), with squared chord distance as the dissimilarity coefficient (DC) (Overpeck et al., 1985). Confidence intervals were based on minimum DC distance within the calibration sets (Laing et al., 1999). Fossil assemblages above the $95 \%$ confidence interval were considered to have no analogues in the calibration set; samples between $75 \%$ and $95 \%$ were considered to have fair analogues (Francis et al., 2006).

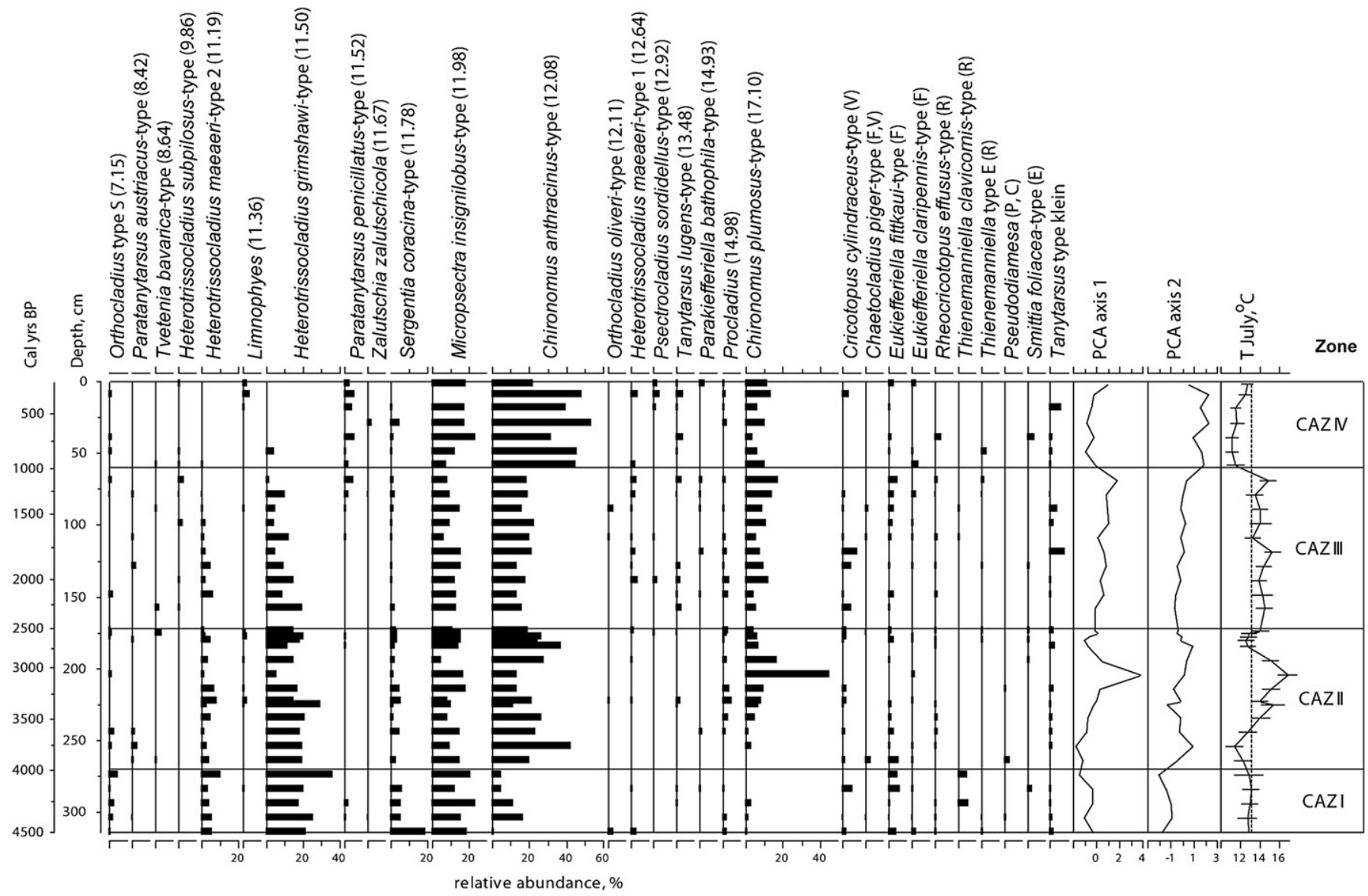

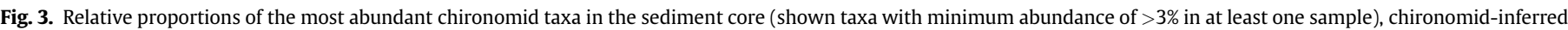

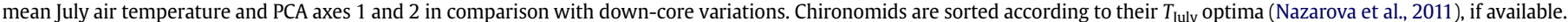

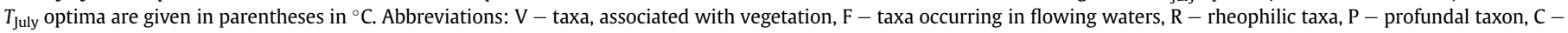
cold-stenotherm, $\mathrm{E}$ - indicator of erosion events. 


\section{Results}

\subsection{Chironomid fauna and taxon richness}

Most of the chironomid head capsules (81.55\%) could be identified to species types and species group level, $4.5 \%$ to tribe level, $12.41 \%$ to genus level and $1.54 \%$ to subfamily level only. In total, we identified 83 taxa within 44 genera and 4 subfamilies. Twenty-six taxa belonged to subfamily Chironominae (12 Chironomini, 13 Tanytarsini and 1 Pseudochironomini), 52 taxa to subfamily Orthocladiinae, 8 taxa to subfamily Diamesinae and 2 to Tanypodinae. The majority $(82.68 \%)$ of the specimens identified only to genus level were Chironomus. This lack of resolution is caused by the frequent absence of mandibles, which are necessary for the identification of Chironomus to the species group level. Due to a lack of some morphologically important features, some specimens of Diamesa, Eukiefferiella, Heterotrissocladius, Paratanytarsus and Protanypus were identified to genus level only.

Some of the Tanytarsini specimens had a distinctive mentum with a small single median tooth and minute outer lateral tooth (Fig. 4). The larvae of this morphotype were found in 20 sediment layers of the core in abundances up to $8.1 \%$, therefore, this form of the mentum cannot be considered as just a morphological abnormality. None of the known Tanytarsini taxa have a similar mentum, so this taxon was treated as a new morphotype and was named 'Tanytarsus type klein'. The taxa appeared at low to moderate abundances throughout the core and could not be associated with colder or warmer periods.

Chironomus anthracinus-type and Chironomus plumosus-type were the most abundant taxa in the studied core, reaching a maximum abundance of $53.85 \%$ and $45.1 \%$, respectively. Heterotrissocladius grimshawi-type ( $\max 36.84 \%$ ), Micropsectra insignilobustype (max 24\%), Sergentia coracina-type (max 19.28\%) and Heterotrissocladius maeaeri-type 2 ( $\max 10.53 \%$ ) also had high abundances throughout the core.

\subsection{Chironomid analysis}

The DCA (square-root transformation of species data, rare taxa downweighted, detrended by segments) revealed that the gradient lengths of axes 1 and 2 were 2.265 and 1.315 standard deviation units, respectively, suggesting that numerical methods based on

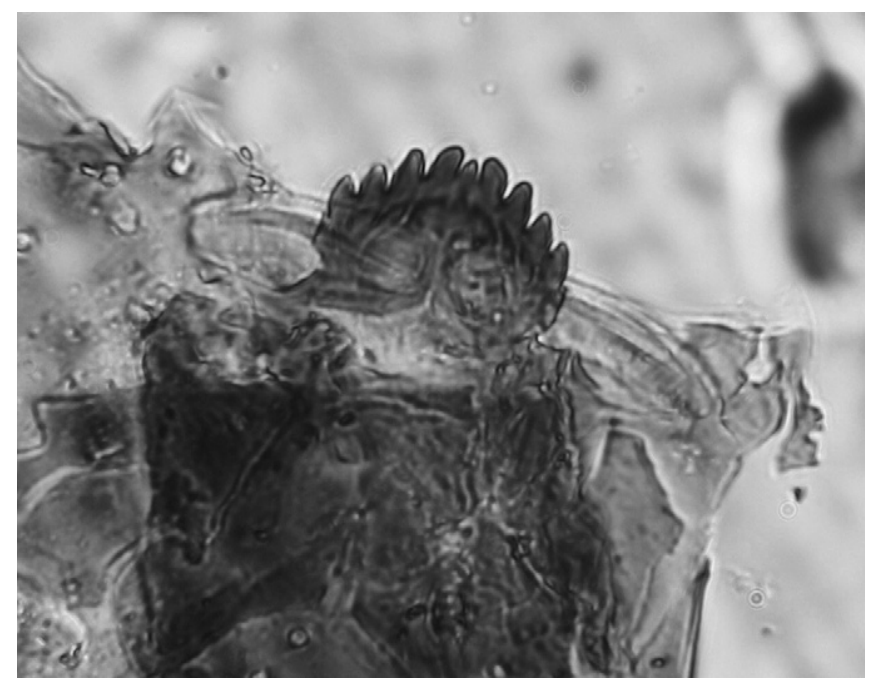

Fig. 4. Morphotype Tanytarsus type klein from the sediment core of the Two-Yurts Lake (Photo Nazarova L.). a linear response model were the most appropriate to assess the structural variation of the chironomid assemblages (ter Braak, 1995). Four significant chironomid assemblage zones (CAZ I-IV) corresponded to trends in sample scores of the first two PCA axes (Fig. 3).

\subsubsection{CAZ I (350-300 cm; 4500 to 4000 cal years BP)}

This zone is characterised by the highest abundances of $H$. grimshawi-type, $H$. maeaeri-type 2, S. coracina-type, Micropsectra insignilobis-type and Orthocladius type S. All of these taxa, except Orthocladius type $\mathrm{S}$, are characterised by relatively deep WD optima (Nazarova et al., 2011) and $T_{\text {July }}$ optima of approximately $12{ }^{\circ} \mathrm{C}$. The warm-water taxa $C$. plumosus-type and Procladius and C. anthracinus-type had low abundances within this zone. Thienemaniella clavicornis-type and Smittia foliacea-type also appear in this interval and both taxa can be indicative of erosion events (Cranston et al., 1983) and streams entering the lake. E. fittkauitype, taxon that is indicative for flowing waters and surface zones of lakes (Cranston et al., 1983), reaches its maximum value at the top of this unit and lower horizon of the next zone. Increase in abundance of these taxa can be indicative for erosion events, most probably connected as well with increase in fluvial alochtonous input into the lake ecosystem. The temperature reconstruction for this zone indicates mean $T_{\text {July }}$ of $12.9 \pm 1.0^{\circ} \mathrm{C}$, which is close to the modern $T_{\text {July. }}$

\subsubsection{CAZ II (300-170 cm; 4000 to 2600 cal years BP)}

Warm-adapted taxa (C. plumosus-type, Procladius) reach maximum values in the middle of this unit and decrease towards the top of the zone. Two other taxa with abundances higher than in other zones are Limnophyes, an indicator of shallow waters (Cranston et al., 1983) and P. austriacus-type. These taxa have low water depth optima in the Yakutian training set (Nazarova et al., 2011). The cold-adapted taxa with high abundances in CAZ I (C. anthracinustype, S. coracina-type, M. insignilobus-type, H. grimshawi-type) show high variability in their abundances and have a decreasing trend towards the depth of $200 \mathrm{~cm}$ (3000 cal years BP).

The reconstructed $T_{\text {July }}$ fluctuates between 11.4 and $16.8{ }^{\circ} \mathrm{C}$. At the beginning of this zone, between 4000 and 3700 cal years BP, $T_{\text {July }}$ remains low. Warming starts up around 3700 cal years BP. The highest value of $16.8{ }^{\circ} \mathrm{C}$ is reconstructed for the middle part of the zone, approximately around 3000 cal years BP. At the end of this zone, around 2800 cal years BP temperature strongly declines, reaching $12.8{ }^{\circ} \mathrm{C}$. Small $T_{\text {July }}$ decline is observed around $3300 \mathrm{cal}$ years BP. The average $T_{\text {July }}$ for this zone is $13.7 \pm 0.8^{\circ} \mathrm{C}$.

\subsubsection{CAZ III (170-51 cm; 2600 to 1000 cal years BP)}

The abundance of $C$. plumosus-type remains at a relatively constant level throughout this unit. The abundances of deep water $H$. grimshawi-type, $H$. maeaeri-type 2 and $S$. coracina-type gradually decrease. $C$. anthracinus-type shows lowest abundances during the entire sequence. Cricotopus cylindraceus-type, a taxon associated with vegetation (Cranston et al., 1983), reaches its maximum abundances in the centre of this unit. An increase in the abundance of C. plumosus-type and E. fittkaui-type is observed towards the upper part of this section. Reconstructed temperatures vary between $12.8{ }^{\circ} \mathrm{C}$ at the beginning of the zone and $15.3^{\circ} \mathrm{C}$ around 1800 cal years BP. Cooling starts around 1100 cal years BP. Mean reconstructed $T_{\text {July }}$ for this zone is $14.2 \pm 0.8^{\circ} \mathrm{C}$.

\subsubsection{CAZ IV (51-0 cm; 1000 to 160 cal years $B P)$}

The uppermost zone is distinguished by higher abundance of some acidification tolerant taxa Limnophies, Zalutschia zalutschicola, H. maeaeri-type, Psectrocladius sordidellus-type (references in Brooks et al., 2007), the highest abundances of cold-adapted 
C. anthracinus-type, $M$. insignilobis-type and a slight recovery of $S$. coracina-type and the disappearance of deep water taxa $H$. grimshawi-type and $H$. maeaeri-type 2. Warm-adapted taxa (C. plumosus-type and Procladius) have low abundances. The appearance of $S$. foliacea-type and Rheocricotopus effusus-type within this interval could indicate a strengthening of the flow in the lake or an erosion event.

Cooling trend, started around 1100 cal years BP led to low temperatures during the CAZ IV. Reconstructed temperatures vary between 11.1 and $12.7{ }^{\circ} \mathrm{C}$, with a mean of $11.7 \pm 0.6{ }^{\circ} \mathrm{C}$, which is below modern $T_{\text {July }}$ values $\left(13^{\circ} \mathrm{C}\right)$.

\subsection{Temperature reconstruction}

The application of transfer functions, inferred from the Yakutian chironomid training data set (Nazarova et al., 2011), resulted in $T_{\text {July }}$ estimates with errors averaging $1{ }^{\circ} \mathrm{C}$, with a clear tendency to decrease towards the top of the core.

All dominant taxa of the fossil record are well represented in the Yakutian training set. Only 3 taxa have a Hill's $N 2<5$ and are therefore defined as not well represented in the Yakutian training set. $R$ h. fuscipes -type $(N 2=2)$ occurs only twice, with abundances of $1.1 \%$ and $1.6 \%$. Chaetocladius piger-type $(N 2=2.8 \%)$ has an abundance of $0.7-3.1 \%$, with only 4 occurrences in the core. Cladotanytarsus mancus-type occurs more often, but always at very low abundances $1.2-2.8 \%$.

Of the 83 chironomid taxa that are identified in the fossil record, 12 are not represented in the modern training set. Most of these taxa have only single occurrences in the fossil record (Corynoneura coronata-type, Diplocladius, Orthocladius oliveri-type, Paracricotopus, Psectrocladius barbatipes-type, Rheocricotopus chalybeatus-type and Stilocladius; not present in Fig. 3), but five taxa occur in higher percentages (Unidentified Diamesini, E. fittkaui-type, Thienemaniella clavicornis-type, Thienemaniella type E and Tanytarsus type klein; Fig. 3). On average, $97 \%$ of the identified chironomid remains of the fossil samples are used in the reconstruction (range: 89.4-100\%).

The first PC axis, which is the major hypothetical gradient in PCA, is significantly correlated with the inferred temperatures $(r=0.7, P \leq 0.05)$. The higher PC axes were not correlated with the inferred temperatures; therefore, secondary gradients cannot be explained by inferred temperature changes.

It is clear from Fig. 5 that the TYL chironomid samples are responding to both $T_{\text {July }}$ and WD with the colder and deeper samples plotted at the right part of the diagram. The performance of the MAT using C2 version 1.5 (Juggins, 2007) showed that all samples

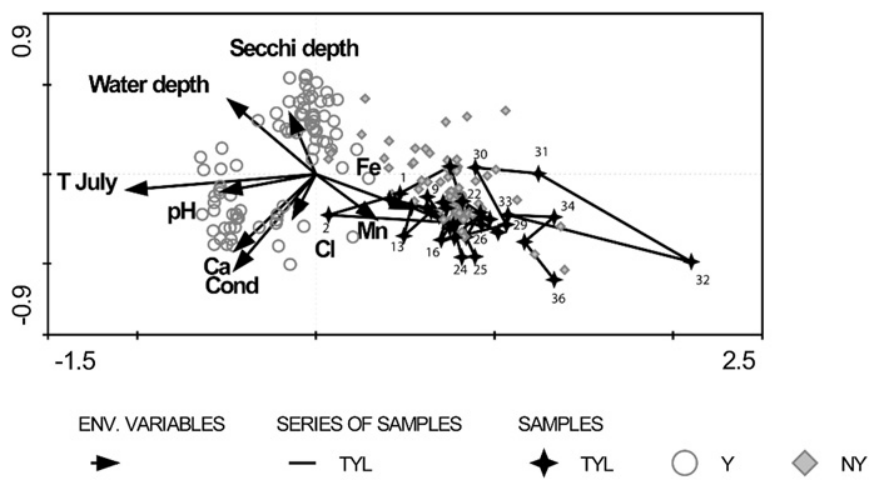

Fig. 5. CCA time-track plot showing the significant environmental variables and training set (Y - Yakutia, NY - northern Yakutia) sites compared against fossil samples from TYL which have been plotted passively. TYL samples are numbered starting from the top of the core. Some of the numbers are omitted in order to avoid crowding of the sample labels. from the TYL sediment core are within the 95\% confidence interval. However, $70 \%$ of the samples have dissimilarity coefficients above $75 \%$ and are considered to have fair analogues (Francis et al., 2006). In all of these samples, E. fittkaui-type, Thienemaniella clavicornistype, Thienemaniella type E and 'Tanytarsus type klein' are present at relatively high abundances. These taxa are quite common throughout the core but not present in the calibration data set. The uppermost samples have the most analogues in the calibration set, whereas the samples from CAZ III have the poorest analogues.

The high representation of the dominant taxa in the Yakutian training set, high correlation of the inferred $T_{\text {July }}$ with the first PC axis and relatively good fit of the fossil samples into the modern training set indicate the reliability of the $T_{\text {July }}$ reconstruction.

\section{Discussion}

\subsection{Chironomid fauna}

Our investigation of the subfossil chironomids from central Kamchatka revealed a rich taxonomic assemblage. The fauna is similar to that from Yakutia, but we observed a relatively high amount of head capsules from the subfamily Diamesinae in Kamchatka (not shown in Fig. 3), whereas almost none were found in Yakutia. Makarchenko et al. (2005) recorded 52 Diamesinae taxa in a catalogue of chironomid fauna of the Russian Far East. High taxonomic richness and abundance of Diamesini may be a distinctive feature of the region. Also, the chironomid fauna of Kamchatka has similarities with the fauna of northwest North America (Barley et al., 2006). In TYL, $61 \%$ of the non-rare taxa are present in the northwest North America training set. We discovered one morphotype of Tanytarsini, Tanytarsus type klein, which is unknown from the other areas. Another distinctive feature of the chironomid fauna is the small-size of most of the chironomid head capsules relative to head capsules from Central and Northern Yakutia.

\subsection{Reconstruction of environmental changes and comparison with other regional studies}

\subsubsection{0 to 3600 cal years $B P$}

Low temperatures are reconstructed from chironomid record of TYL for the initial stage of the Late Holocene (4500-3600 cal years $\mathrm{BP})$. In accordance with our study, analyses of diatom assemblages and diatom oxygen isotopic composition of the TYL sediment core suggest a rather cool climate from 4570 to 3600 cal years (Hoff, 2010). Since ca 6000 years BP, continentality tended to increase in the region, which was caused by weakening of the Pacific influence while the impact of Siberian High strengthened progressively (Mayewski et al., 2004; Dirksen and Dirksen, 2008). But between ca 4500 and 3500 years BP continentality decreased (Dirksen and Dirksen, 2008) which is in good agreement with a Neoglacial cooling event, widely reported from the Asian mainland and other parts of the northern Pacific (Kuhle, 2004). A wellpronounced cooling occurred $\sim 4500-4700$ cal years BP on the mainland of the South Far East and on Sakhalin Island (Khotinsky, 1977; Mikishin and Gvozdeva, 1996; Korotky et al., 2005). The maximum Neoglaciation extent in central Kamchatka (Sredniaya Avacha) was reached by the largest glaciers between 4300 and 3500 years BP (lichenometry dates (L) (Fig. 6F), although smaller glaciers reached their maximum extent later, between 3300 and 2800 years BP (L). But none of the glaciers exceeded its preHolocene thermal maximum (HTM) limit (Savoskul, 1999).

The study of Late Holocene climate development on Kunashir and Iturup Islands (Kurile Islands) and Bering Island (Komandor Islands) (Razjigaeva et al., 2004) (Fig. 1), has shown that the beginning of the cold period at the middle-late Holocene boundary 


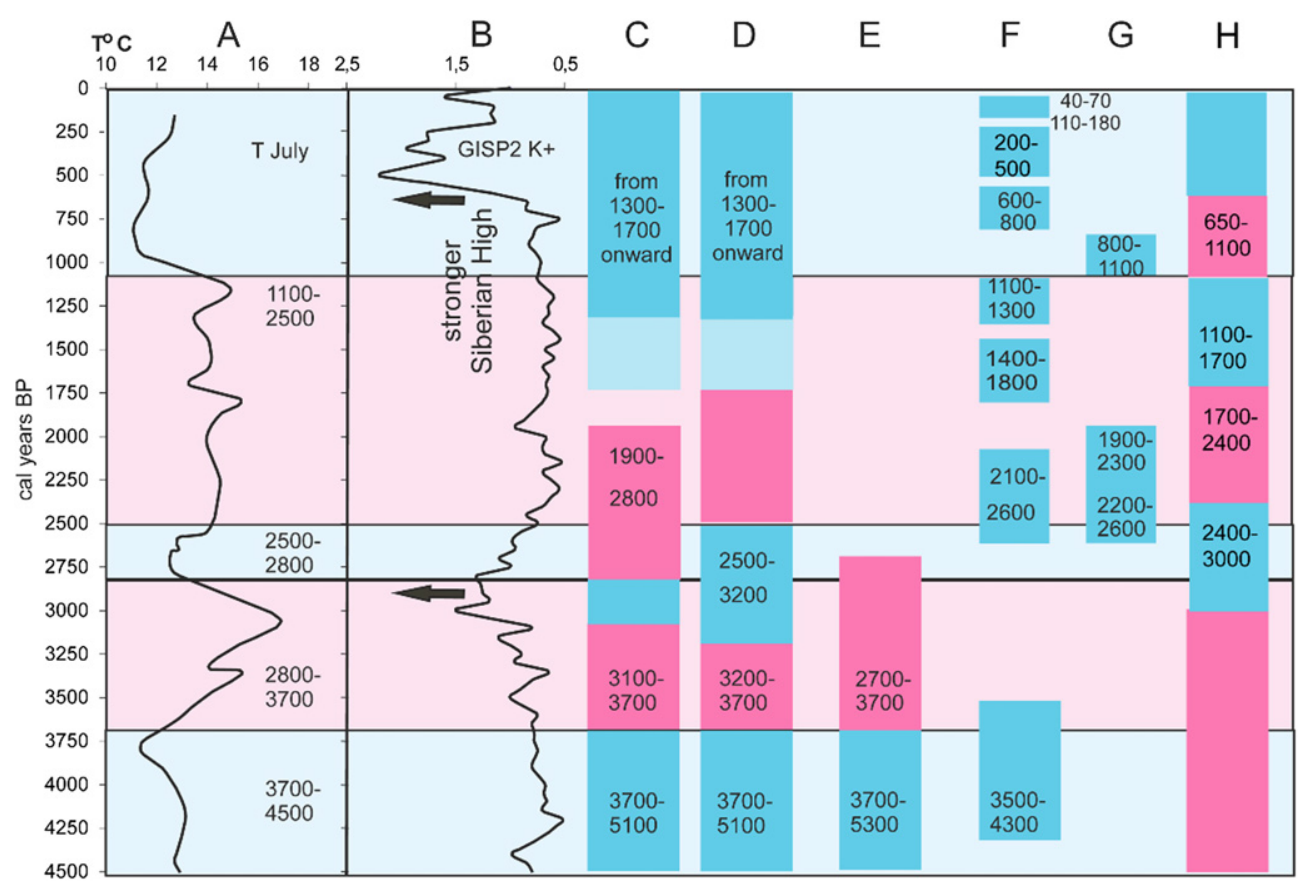

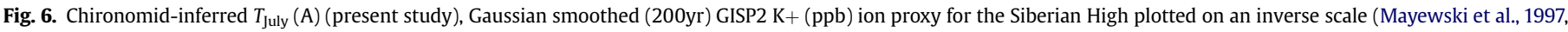

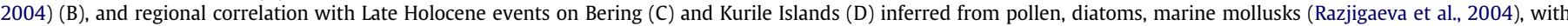

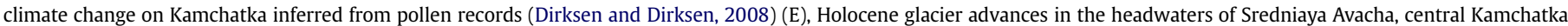

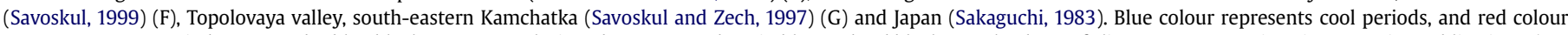

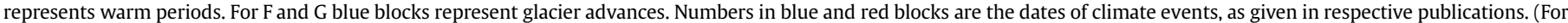
interpretation of the references to color in this figure legend, the reader is referred to the web version of this article.)

is dated about $4600-4500$ years BP (5100-5300 cal years BP) (Fig. 6C and D). Cooling was more pronounced in the Central islands as compared to the South Kurils. It had little impact on the vegetation of the North Kuril Islands, where changes in the pollen record are minor (Lozhkin et al., 2010; Razjigaeva et al., 2011). Despite climatic deterioration, island vegetation changed very little due to the ameliorating influence of warm currents. The most significant regression of sea-level in the middle-late Holocene is connected with this cooling.

This regression is correlated with the middle Jomon regression or Kemigawa regression of the Japan Islands (Razjigaeva et al., 2004). On the Japanese Islands, a general cooling trend began after 4000 years BP ( 4500 cal years BP) (Fig. $6 \mathrm{H}$ ). The summer temperatures were lower during the late Holocene, while the winter temperatures did not change appreciably and precipitation increased.

Dirksen and Dirksen (2008) reconstructed a cold and wet period between 4500 and 3500 years BP (5300-3700 cal years BP) from pollen records in Kamchatka (Fig. 6E). High amount of precipitation may have led to increase in fluvial allochthonous input into the lake ecosystem and higher than present lake levels. Landslides also may be induced by intense precipitation, which probably may explain the occurrence of the taxa indicative for erosion events, surf zone of lakes, floating waters and rivers (Smittia foliacea-type, Thienemaniella, E. fittkaui-type) in chironomid assemblages. The modern TYL is located in a former proglacial valley bordered by steep slopes, therefore changes in water depth can occur without significant changes in the surface area and littoral zone of the lake. There are two paleo-lake terraces around TYL, suggesting a higher lake level in the past, but comprising only a small surface area (Dirksen et al., 2011). The surrounding relief satisfies the prerequisites needed for landslides. The higher lake level may have resulted from landslides retaining the water, whereas subsequent retrograde erosion may have led to a re-lowering of the lake level. The increase in pollen from Alnus fruticosa, starting at the top of this zone (Dirksen; personal communication), supports this hypothesis. It is a pioneer species that, due to its ability to fix atmospheric nitrogen through a symbiosis with ray fungus, can grow on raw soils.

\subsubsection{0 and 1100 cal years $B P$}

Late Holocene climate is characterized by fluctuating short-term cooling and warming events (Razjigaeva et al., in press). According to the chironomid record of TYL, warming started around 3700 cal years BP (Fig. 6A). Warm-water taxa (C. plumosus-type, Procladius) reached their maximum values between 3700 and 1100 cal years BP and cold-adapted taxa (Heterotrissocladius and Sergentia) decreased moderately, indicating a warmer climate, especially between 3500 and 2800 cal years BP. Reconstructed mean July air temperatures reached $16.8^{\circ} \mathrm{C}$, which is $>3^{\circ} \mathrm{C}$ higher than present day temperatures. Corresponding diatom assemblages in TYL also suggested warm climatic conditions, as indicated by the presence of Cyclotella ocellata Pantocsek (Hoff, 2010). Chironomid evidence of warming between 3700 and 2800 cal years BP is consistent with the second maximum of spreading of stone birch forests on both coasts of the peninsula during this time (Dirksen and Dirksen, 2008). On Bering Island, first warming stages, accompanied by small magnitude transgressions, were reconstructed from diatom data (Fig. 6C). On the South Kurils sea-level rise about 3500 year BP (3700 cal years BP) resulted in the development of small estuary lagoons that existed until the cooling at about 3000 years BP (3100 cal years BP).

Between 2800 and 2500 cal years BP chironomid-inferred temperatures declined to $12.5-12.8{ }^{\circ} \mathrm{C}$. In Topolovaya valley, south-eastern Kamchatka, a maximum post-HTM advance of glaciers was reported between 2200 and 2600 years BP (L) (Savoskul and Zech, 1997) (Fig. 6G). Three advances of smaller magnitude 
occurred in the central Kamchatka ca 2600-2100, 1800-1400, and 1300-1100 (L) years BP (Fig. 6F).

In the Kuril Islands, cooling, corresponding to the second half of the Subboreal, resulted in considerable landscape changes. On the South Kuriles, a significant climatic deterioration indicated by pollen results took place after 3000-2500 years BP (32002500 cal years BP) (Fig. 6D). The decrease of mean annual temperatures in Japan (Latest Jomon cold stage $\sim 3000-2400$ cal years BP) (Fig. 6H) was estimated to be $\sim 2-3{ }^{\circ} \mathrm{C}$ and is associated with greater winter precipitation (Sakaguchi, 1983; Yasuda, 1995).

The second warm interval inferred from chironomids of TYL (2500-1100 cal years BP) is characterised by fluctuations in the relative abundances of warm-adapted chironomid fauna (Procladius and $H$. maeaeri-type 1$)$. Reconstructed temperatures vary around $14{ }^{\circ} \mathrm{C}$, reaching $15.3^{\circ} \mathrm{C}$ at about $1800 \mathrm{cal}$ years BP. On Bering Island, second warming stage, accompanied by small magnitude transgressions, was reconstructed from diatom data after 2500 cal years BP (Fig. 6C). On the South Kuriles sea-level rise (up to $1.5 \mathrm{~m}$ above modern sea-level position) took place between 2700 and 2000 years BP (2800 and 1900 cal years BP).

On Bering Island, the next cooling took place about 1800-1400 years BP (1700-1300 cal years BP) (Razjigaeva et al., 1994). Pronounced cooling coincident with a slight sea-level regression on the South Kurile and Japan Islands was established about 17001300 years BP. This cooling is correlated with the Kofun cold stage of the Japan Islands (Sakaguchi, 1983; Razjigaeva et al., 2004) (Fig. 6C, D, H). Vegetation changes seem to have been caused by climatic deterioration and marine current influences. At this time, warm stream activity in the Okhotsk Sea decreased significantly (Taira and Lutaenko, 1993). The Oyashio Current was possibly more active, leading to an increase in fog and drizzle and a more intense wind regime. The sum of active temperatures along the islands' shores, which experience the greatest impact of marine conditions, is presumed to be no higher than $700-1000^{\circ} \mathrm{C}$. The combination of increased precipitation and falling temperatures on north-western Pacific Islands during the late Holocene introduced a degree of instability in their environments (Razjigaeva et al., 2004).

\subsubsection{0 to 160 cal years $B P$}

The last millennium in the sediment record of TYL is characterised by a gradual increase in taxa that are indicative of climate cooling ( $S$. coracina-type, $C$. anthracinus-type). Cooling trend, started around 1100 cal years BP led to low temperatures during the last stage of the Holocene. Reconstructed temperatures vary around $11.7^{\circ} \mathrm{C}$, which is below modern $T_{\text {July. }}$ Increased abundances of taxa commonly found in acidic or humic lakes (Psectrocladius sordidellus-type (Walker and Mathewes, 1989); Z. zalutschicola (Sæther, 1979; Walker et al., 1985) may also reflect an increase in humic acid inputs during this period. A higher incidence of coniferous species resulted in a "Coniferous Island", which may explain the natural acidification (Dirksen and Dirksen, 2008). Analysis of diatom assemblages in TYL sediments led to a reconstruction of similar environmental conditions (Hoff, 2010).

The Nara-Heian-Kamakura warm stage (1270-700 years BP, 1100-650 cal years BP) (Fig. 6H), identified in Japan, that corresponded to the Medieval Warm Period (Adhikari and Kumon, 2001), was characterized by warm winters, relatively hot summers, and decreased precipitation (Sakaguchi, 1983). This warm period was not found in our investigation and was not pronounced on the Bering and Kuril Islands (Fig. 6C and D), most probably because of the declining impact of warm marine waters during the Late Holocene (Koizumi, 1994). The warming on Kuril Islands was less pronounced than in continental regions of the South Far East, where the average temperatures deviations compared to modern was $\sim 1{ }^{\circ} \mathrm{C}$ (Korotky et al., 2005; Velichko, 2010; Razjigaeva et al., in press).
Based on tephrochronological dating, last glaciers advanced in central Kamchatka took place after 1400 years BP (Savoskul, 1999). Lichenometry provides evidence that moraines were formed $800-$ $600,500-200,180-110$, and 70-40 (L) years BP (Fig.6F). However, the accuracy of the lichen growth curve in the range between 10 and $30 \mathrm{~mm}$ is poor. Nevertheless, although the absolute chronology given by Savoskul (1999) may be imprecise, last glacier advances fall completely within the past 1000 years and are in agreement with climate cooling reconstructed from TYL sediments. These glacier advances most probably can represent the Little Ice Age (LIA) (Savoskul, 1999).

Diatom record of the upper part of the sediment record of the lake Sigrid, located near the TYL, showed that the last 500 years were likely characterized by summer cooling and may represent the Little Ice Age (Hoff et al., 2012). Pollen spectra in peat sections along the Pacific coast of Kamchatka also indicate climate deterioration after 1550 BC (Dirksen and Uspenskaya, 2005). Tree-ring and ice-core records only extend back 400 years, but also provide evidence for cold climate conditions during the Little Ice Age (Solomina et al., 2007).

The Little Ice Age was a key palaeoclimatic event that strongly influenced the formation of the modern Kuril landscapes (Razjigaeva et al., in press). This period in the Central Kurils was characterized by an increase in effective moisture, snow cover thickness, and peat accumulation rates. Quantitative analysis of temperature changes using geothermal and tree-ring data for the last 400 years on Kunashir Island (Demezhko and Solomina, 2009) indicates that the temperature of the earth surface in the 17th19th centuries was $\sim 2{ }^{\circ} \mathrm{C}$ lower than modern. This change was also associated with an increase in snow cover. Reconstructed temperatures from the South Kurils correspond well with data from Japan (Kitagawa and Matsumoto, 1995). In Japan, this period (after 650 BP) (Fig. 6H) was characterized by cold winters, cool summers, and high precipitation, with mean annual temperatures decreasing by $1-2{ }^{\circ} \mathrm{C}$ (Taira, 1980; Sakaguchi, 1983). The regional cooling was likely enhanced along the southern Kuril Ridge as the warm marine current shifted to the south (Koizumi, 1994; Kawahata et al., 2003) and the influence of the cold Oyashio current was intensified. This cooling was accompanied by a marine regression. The exposure of vast areas of marine benches and shallow waters, covered by friable sediments, and greater Aeolian activity promoted the formation of coastal dunes in the Kuril Islands.

Thereby, termination of cooling at the beginning of late Holocene is relatively synchronous in central Kamchatka, South Kurile, Bering and Japanese Islands (this study; Savoskul and Zech, 1997; Savoskul, 1999; Razjigaeva et al., 2004; Dirksen and Dirksen, 2008; Hoff et al., 2012) and take place around 3700 cal years BP. From ca 3700 cal years BP to the last millennium, a newly strengthened climate continentality accompanied by general warming trend with minor cool excursions led to apparent spatial heterogeneity of climatic patterns. Two warm stages reconstructed from chironomid record between 3700 and 2800 cal years BP and 2500 and 1100 cal years BP are in a good agreement with the pollen data (Dirksen and Dirksen, 2008) and glaciers retreat in central and south-eastern Kamchatka (Savoskul and Zech, 1997; Savoskul, 1999). Two warm periods in Bering and Kurile Islands are recorded for earlier time periods: between 3700 and 3100 cal years BP and 2800 to 1900 cal years BP (Razjigaeva et al., 2004). Second glaciers advance in central and south-eastern Kamchatka partly coincide with short climate deterioration, inferred from chironomids between 2800 and 2500 cal years BP and can be related to Latest Jomon cold stage in Japan. Reconstructed from chironomids cooling started around 1100 cal years BP, which is later than on Kurile and Bering Islands, but fit relatively well to the last glacier advances in central Kamchatka. Some timing differences in climatic 
changes reconstructed from chironomid record of TYL sediments and late Holocene events reconstructed from other sites and other proxies might be linked to differences in local forcing mechanisms or caused by the different degree of dating precision, the different temporal resolution, and the different sensitive responses of climate proxies to the climate variations.

Our reconstruction shows certain agreement with a global study of Holocene climate variability (Mayewski et al., 1997, 2004), which used potassium ion depositions in the GISP2 record as a proxy for the strength of the Siberian High. The warm period reconstructed for Kamchatka (at 3600 to 1100 cal years BP) corresponds to a weak Siberian High (Mayewski et al., 1997) (Fig. 6B). The inferred cold period over the last 1000 cal years BP corresponds partly to high values in the GISP2 potassium ion proxy linked with a strong Siberian High (Mayewski et al., 1997, 2004).

Chironomid record derived from volcanic-affected areas on Kamchatka suggests a complicated environmental response to regional climate change. Climate changes over the past millennium in the north-western Pacific are believed to have been driven by sea-level changes (Razjigaeva et al., 2004). Another major factor influencing environments was numerous ash falls from local volcanoes (Dirksen and Dirksen, 2008; Dirksen et al., 2011). Complexity of Holocene climate in the region highlights again the importance of having site-specific palaeoclimatic data to avoid the risk of using data series from one area to extrapolate to another (Mayewski et al., 2004). Well-dated, high-resolution climate proxy records are essential for understanding the natural climate variability and climate driving mechanisms. Further high-resolution stratigraphic studies in this region are needed to understand the spatially complex pattern of climate change in Holocene in Kamchatka and the surrounding region.

\section{Conclusion}

This study presents a reconstruction of the Late Holocene climate in Kamchatka based on chironomid remains from TYL. Chironomid head capsules from TYL reflect a rich and diverse fauna, which is similar to those from Yakutia and northwest North America. An unknown morphotype of Tanytarsini, Tanytarsus type klein, was found in the lake sediments. Our analysis reveals four chironomid assemblage zones reflecting four different climatic periods in the late Holocene. Between 4500 and 4000 cal years BP, the chironomid composition indicates a high lake level, well-oxygenated lake water conditions and moderate, near-present day temperatures. From 4000 to 1000 cal years BP, two consecutive warm intervals were recorded, with the highest temperature reaching $16.8^{\circ} \mathrm{C}$ for the time between 3700 and 2800 cal years BP. After 1000 cal years BP, the chironomid record suggests temperatures lower than present day and lowering of the lake level with the onset of natural acidification. Cooling trend, started around 1100 cal years BP led to low temperatures during the last stage of the Holocene. Comparison with other regional studies has shown that termination of cooling at the beginning of late Holocene is relatively synchronous in central Kamchatka, South Kurile, Bering and Japanese Islands and take place around 3700 cal years BP. From ca 3700 cal years BP to the last millennium, a newly strengthened climate continentality accompanied by general warming trend with minor cool excursions led to apparent spatial heterogeneity of climatic patterns in the region.

\section{Acknowledgements}

We thank all of our Russian and German colleagues, who helped us during fieldwork in Kamchatka. Sincere thanks to anonymous reviewers for their valuable comments. This study is part of a Russian-German joint project KALMAR (Kurile-Kamchatka and
Aleutian Marginal Sea-Island Arctic Systems: Geodynamic and Climate interactions in Space and Time) and the German-Russian cooperative scientific efforts of the Alfred Wegener Institute for Polar and Marine Research.

\section{References}

Adhikari, D.P., Kumon, F., 2001. Climatic changes during the past 1300 years as deduced from the sediments of Lake Nakatsuna, central Japan. Limnology 2 157-168.

Andreeva, E.D., Buhanova, D.S., Konovalova, N.S., 2008. Novye dannye o sulfidah dvuhyurtochnoj gidrotermalnoj sistemy (Centalnaja Kamchatka). Materialy VI regionalnoj molodezhnoj nauchnoj konferencii "Issledovania v oblasti nauk o Zemle" 26-27 November 2008, Petropavlovsk-Kamchatskiy (in Russian). (New data on sulfides from the Two Yurts thermal system (Central Kamchatka). Materials of the VI Regional Youth Scientific Conference (Investigations in the Field of Earth Sciences).

Barley, E.M., Walker, I.R., Kurek, J., Cwynar, L.C., Mathewes, R.W., Gajewski, K. Finney, B.P., 2006. A northwest North American training set: distribution of freshwater midges in relation to air temperature and lake depth. Journal of Paleolimnology 36, 295-314.

Battarbee, R.W., 2000. Palaeolimnological approaches to climate change, with special regard to the biological record. Quaternary Science Reviews 19, 107-124.

Beierle, B., Bond, J., 2002. Density-induced settling of tephra through organic lake sediments. Journal of Paleolimnology 28, 433-440.

Bennett, K.D., 1996. Determination of the number of zones in a biostratigraphical sequence. New Phytologist 132, 155-170.

Bigg, G.R., Clark, C.D., Hughes, A.L.C., 2008. A last glacial ice sheet on the Pacific Russian coast and catastrophic change arising from coupled iceevolcanic interaction. Earth and Planetary Science Letters 265, 559-570.

Birks, H.J.B., Gordon, A.D., 1985. Numerical Methods in Quaternary Pollen Analysis. Academic Press, London.

Brooks, S.J., Birks, H.J.B., 2000. Chironomid-inferred late-glacial and early-Holocene mean July air temperatures for Kråkenes Lake, western Norway. Journal of Paleolimnology 23, 77-89.

Brooks, S.J., Birks, H.J.B., 2001. Chironomid-inferred air temperatures from lateglacial and Holocene sites in north-west Europe: progress and problems. Quaternary Science Reviews 20, 1723-1741.

Brooks, S.J., Langdon, P.G., Heiri, O., 2007. Using and Identifying Chironomid Larvae in Palaeoecology. QRA Technical Guide $\mathcal{N} \circ$ 10. Quaternary Research Association, London.

Cranston, P.S., Oliver, D.R., Saether, O.A., 1983. The larvae of the Orthocladiinae (Diptera: Chironomidae) of the Holarctic region. Keys and diagnoses. Entomologica Scandinavica Supplement 19, 149-291.

Danzeglock, U., Jöris, O., Weninger, B., 2010. CalPal-2007. Online available at: http:// www.calpal-online.de (accessed 06.03.11).

Demezhko, D. Yu., Solomina, O.N., 2009. Ground surface temperature change in Kunashir Island inferred from borehole data and tree-ring chronology. Doklady Akademii Nauk 426, 240-243.

Dirksen, O., van den Bogaard, C., Danhara, T., Diekmann, B., 2011. Tephrochronological investigation at Dvuh-yurtochnoe lake area, Kamchatka: numerous landslides and lake tsunami, and their environmental impacts. Quaternary International 246, 298-311.

Dirksen, V., Dirksen, O., 2008. Late Pleistocene to Holocene climate change on Kamchatka, Russian Far East, inferred from pollen records. Geophysical Research Abstracts 7. EGU2008-A-10287.

Dirksen, V.G., Uspenskaya, O.N., 2005. Holocene climate and vegetation changes in Eastern Kamchatka based on pollen, macrofossil and tephra records. Geophysical Research Abstracts 7. EGU05-A-01435.

Engels, S., Helmens, K.F., Väliranta, M., Brooks, S.J., Birks, H.J.B., 2010. EarlyWeichselian (MIS 5d and 5c) temperatures and environmental changes in northern Fennoscandia as recorded by chironomids and macroremains at Sokli, northeast Finland. Boreas 39, 689-704.

Fradkina, A.F., Grinenko, O.V., Laukhin, S.A., Nechaev, V.P., Andreev, A. Klimanov, V.A., 2005. Northeastern Asia. In: Velichko, A.A., Nechaev, V.P. (Eds.) Cenozoic Climatic and Environmental Changes in Russia. Geological Society of America, Special Paper, pp. 105-120.

Francis, R.D., Wolfe, A.P., Walker, I.R., Miller, G.H., 2006. Interglacial and Holocene temperature reconstructions based on midge remains in sediments of two lakes from Baffin Island, Nunavut, Arctic Canada. Palaeogeography, Palaeoclimatology, Palaeoecology 236, 107-124.

Hill, M.O., 1973. Diversity and evenness: a unifying notation and its consequences Ecology 54, 427-432.

Hoff, U., 2010. Freshwater diatoms as indicators for Holocene environmental and climate changes on Kamchatka, Russia, PhD thesis, Alfred Wegner Institute; University of Potsdam, Potsdam.

Hoff, U., Dirksen, O., Dirksen, V., Herzschuh, U., Hubberten, H.-W., Meyer, H., van den Bogaard, C., Diekmann, B., 2012. Late Holocene diatom assemblages in a lake-sediment core from Central Kamchatka, Russia. Journal of Paleolimnology $47,549-560$.

Juggins, S., 2007. C2 Version 1.5 User Guide. Software for Ecological and Palaeoecological Data Analysis and Visualisation. Department of Geography, University of Newcastle, Newcastle upon Tyne. 
Kawahata, H., Ohshima, H., Shimada, C., Oba, T., 2003. Terrestrialeoceanic environmental change in the southern Okhotsk Sea during the Holocene. Quaternary International $108,67-76$.

Khotinsky, N.A., 1977. Holocene of the Northern Eurasia. Nauka, Moscow (in Russian).

Kienast, F., Wetterich, S., Kuzmina, S., Schirrmeister, L., Andreev, A., Tarasov, P., Nazarova, L., Kossler, A., Frolova, L., Kunitsky, V., 2011. Paleontological records prove boreal woodland under dry inland climate at today's Arctic coast in Beringia during the last interglacial. Quaternary Science Reviews 31, 2134-2159.

Kitagawa, H., Matsumoto, E., 1995. Climatic implications of d13C variations in a Japanese cedar (Cryptomeria japonica) during the last two millenia. Geophysical Research Letters 22, 2155-2158.

Koizumi, I., 1994. Spectral analysis of the diatom paleotemperature records at DSDP sites 579 and 580 near the subarctic front in the western North Pacific. Palaeogeography, Palaeoclimatology, Palaeoecology 108, 475-485.

Kokorowski, H.D., Anderson, P.M., Mock, C.J., Lozhkin, A.V., 2008. A re-evaluation and spatial analysis of evidence for a Younger Dryas climatic reversal in Beringia. Quaternary Science Reviews 27, 1710-1722.

Korotky, A.M., Volkov, V.G., Grebennikova, T.A., Razzhigaeva, N.G., Pushkar, V.S Ganzei, L.A., Mokhova, L.M., 2005. Far east. In: Velichko, A.A. (Ed.), Cenozoic Climate and Environmental Changes in Russia. Book Series: Geological Society of America Special Papers, vol. 382, pp. 121-137.

Krestov, P.V., Omelko, A.M., Nakamura, Y., 2008. Vegetation and Natural Habitats of Kamchatka. Ber. d. Reinh.- Tüxen-Ges, Hannover 20, pp. 195-218.

Kuhle, M., 2004. The High Glacial (Last Ice Age and LGM) ice cover in high and Central Asia. Development in Quaternary Science 2c. In: Ehlers, J., Gibbard, P.L. (Eds.), Quaternary Glaciation - Extent and Chronology, Part III: South America, Asia, Africa, Australia, Antarctica. Elsevier B.V., Amsterdam, pp. 175-199.

Kumke, T., Kienel, I., Wekström, J., Korhola, A., Hubberten, H.-W., 2004. Inferred Holocene paleotemperatures from diatoms at Lake Lama, Central Siberia. Arctic, Antarctic and Alpine Research 36, 624-634.

Laing, T.E., Rühland, K.M., Smol, J.P., 1999. Past environmental and climatic changes related to tree-line shifts inferred from fossil diatoms from a lake near the Len River Delta, Siberia. Holocene 9, 547-557.

Larocque, I., Hall, R.I., Grahn, E., 2001. Chironomids as indicators of climate change: a 100-lake training set from a subarctic region of northern Sweden (Lapland) Journal of Paleolimnology 26, 307-322.

Larocque, I., 2001. How many chironomid head capsules are enough? A statistical approach to determine sample size for palaeoclimatic reconstructions. Palaeogeography, Palaeoclimatology, Palaeoecology 172, 133-142.

Lodis, F.A., Semenov, V.I., 1993. Kamchatka - kraj lechebnyj. Petropavlovskkamchatskiy: Dalnevostochnoe knizhnoe izdatelstvo, kamchatskoe otdelenie (in Russian) (Kamchatka - therapeutic region).

Lotter, A.F., Juggins, S., 1991. POLPROF, TRAN and ZONE: programs for plotting editing and zoning pollen and diatom data. Inqua-Subcommission for the study of the Holocene, Working Group on Data-Handling Methods. Newsletter 6, 4-6.

Lotter, A.F., Hölzer, A., 1989. Spätglaziale Umweltverhältnisse im Südschwarzwald: Erste Ergebnisse paläolimnologischer und paläoökologischer Untersuchungen an Seesedimenten des Hirschenmoores. Carolinea 47, 7-14.

Lozhkin, A.V., Anderson, P.M., Goryachev, N.A., Minyuk, P.S., Pakhomov, A. Yu. Solomatkina, T.B., Cherepanova, M.V., 2010. First lake record of Holocene climate and vegetation changes of the northern Kuril Islands. Doklady Akademii Nauk 430, 541-543.

Makarchenko, E.A., Makarchenko, M.A., Zorina, O.V., Sergeeva, I.V., 2005. Preliminary data on fauna and taxonomy of Chironomids (Diptera, chironomidae) of Russian Far East. Vladimir Y. Levanidov's Biennial Memorial Meetings 3, 394 420.

Mayewski, P.A., Meeker, L.D., Twickler, M.S., Whitlow, S., Yang, Q. Lyons, W.B Prentice, M., 1997. Major features and forcing of high-latitude northern hemisphere atmospheric circulation using a 110,000-year-long glaciochemical series. Journal of Geophysical Research 102, 26345-26366.

Mayewski, P.A., Rohling, E.E., Stager, J.C., Karlén, K.A., Maasch, W., Meeker, L.D. Meyerson, E.A., Gasse, F., van Kreveld, S., Holmgren, K., Lee-Thorp, J. Rosqvist, G., Rack, F., Staubwasser, M., Schneider, R.R., Steiger, E.J., 2004. Holocene climate variability. Quaternary Research 62, 243-255.

Mikishin, Yu. A., Gvozdeva, I.G., 1996. The Natural Evolution in the South-eastern Part of Sakhalin Island in Holocene. Publishing FESU, Vladivostok (in Russian).

Nazarova, I., 1999. Kamchatka regional profile. International Market Insight Report $3,1-9$

Nazarova, L., Herzschuh, U., Wetterich, S., Pestryakova, L., 2011. Chironomid-based inference models for estimating mean July air temperature and water depth from lakes in Yakutia, northeastern Russia. Journal of Paleolymnology 45, 57-71.

Nazarova, L.B., Pestryakova, L.A., Ushnitskaya, L.A., Hubberten, H.-W., 2008. Chironomids (Diptera: Chironomidae) in lakes of Central Yakutia and their indicative potential for paleoclimatic research. Contemporary Problems of Ecology $1,335-345$.

Nazarova, L., 2012. Chironomids in Quaternary permafrost deposits in the Siberian Arctic. Chironomus. Newsletter of Chironomid Research 25, 39-42.

Nazarova, L., Lüpfert, H., Subetto, D., Pestryakova, L., Diekmann, B. Holocene climate conditions in central Yakutia (Eastern Siberia) inferred from sediment composition and fossil chironomids of Lake Temje. Quaternary International. Corrected Proof, http://dx.doi.org/10.1016/j.quaint.2012.11.006, in press.

Neshataeva, V., 2008. The Plant Cover of the Kamchatka Peninsula (North of the Russian Far East). Komarov Botanical Institute Russian Press, St.-Petersburg, Russia.
New, M., Lister, D., Hulme, M., Makin, I., 2002. A high-resolution data set of surface climate over global land areas. Climate Research 21, 1-25.

Overpeck, J.T., Webb, T., Prentice, I.C., 1985. Quantitative interpretation of fossil pollen spectra: dissimilarity coefficients and the method of modern analogs. Quaternary Research 23, 87-108.

Pisaric, M.F.J., Macdonald, G.M., Velichko, A.A., Cwynar, L.C., 2001. The lateglacial and postglacial vegetation history of the northwestern limits of Beringia, based on pollen, stomata and tree stump evidence. Quaternary Science Reviews 20, 235-245.

Quinlan, R., Smol, J.P., 2001. Chironomid-based inference models for estimating end-of-summer hypolimnetic oxygen from south-central Ontario shield lakes. Freshwater Biology 46, 1529-1551.

Razjigaeva, N.G., Grebennikova, T.A. Ganzey, LA, Mokhova, L.M., Chuyan, G.N. 1994. Tectonic and sea level oscillation factors in formation of Bering Islands marine terraces. In: Viggosson, G. (Ed.), Proc. of Hornafjordur International Coastal Symposium, Iceland, June 20-24, 1994. The Organizing Committee of the Symposium, Reykjavik, pp. 543-552.

Razjigaeva, N.G., Grebennikova, T.A., Ganzey, L.A., Mokhova, L.M., Bazarova, V.B., 2004. The role of global and local factors in determining the middle to late Holocene environmental history of South Kurile and Komandar island, northwestern Pacific. Palaeogeography, Palaeoclimatology, Palaeoecology 209, 313-333.

Razjigaeva, N.G., Ganzey, L.A., Arslanov, Kh.A., Grebennikova, T.A., Belyanina, N.I., Mokhova, L.M., 2011. Paleoenvironments of Kuril Islands in Late PleistoceneeHolocene: climatic changes and volcanic eruption effects. Quaternary International 237, 4-14

Razjigaeva, N.G., Ganzey, L.A., Grebennikova, T.A., Belyanina, N.I., Mokhova, L.M., Arslanov K.A., Chernov, S.B. Holocene climatic changes and vegetation development in the Kuril Islands. Quaternary International. Corrected Proof, http:// dx.doi.org/10.1016/j.quaint.2012.06.034, in press.

Sæther, O.A., 1979. Chironomid communities as water quality indicators. Holarctic Ecology 2, 65-74.

Sakaguchi, Y., 1983. Warm and cold stages in the past 7600 years in Japan and their global correlation. Bulletin of the Department of Geography University of Tokyo 15, 1-31.

Sano, M., Furuta, F., Sweda, T., 2009. Tree-ring-width chronology of Larix gmelinii as an indicator of changes in early summer temperature in east-central Kamchatka. Journal of Forest Research 14, 147-154.

Sano, M., Furuta, F., Sweda, T., 2010. Summer temperature variations in southern Kamchatka as reconstructed from a 247-year tree-ring chronology of Betula ermanii. Journal of Forest Research 15, 234-240.

Savoskul, O., 1999. Holocene glacier advances in the headwaters of Sredniaya Avacha, Kamchatka, Russia. Quaternary Research 52, 14-26.

Savoskul, O.S., Zech, W., 1997. Holocene glacier advances in the Topolovaya valley, Bystrinskiy range, Kamchatka, Russia, dated by tephrochronology and lichenometry. Arctic and Alpine Research 29, 143-155.

Self, A.E., Brooks, S.J., Birks, H.J.B., Nazarova, L., Porinchu, D., Odland, A., Yang, H., Jones, V.J., 2011. The distribution and abundance of chironomids in highlatitude Eurasian lakes with respect to temperature and continentality: development and application of new chironomid-based climate-inference models in northern Russia. Quaternary Science Reviews 30, 1122-1141.

Shiraiwa, T., Tchoumitchev, S.A., 2002. Mountain Environment in Kamchatka: Physical Background and Recent Changes in the Climate and Glaciers. Technical Report. The Institute of Low Temperature Science and the Graduate School of Environmental Earth Science, Hokkaido University, Kitaku, Sapporo, Japan.

Smol, J.P., Wolfe, A., Birks, H.J.B., Douglas, M.S.V., Jones, V.J., Korhola, A., Pienitz, R, Rühland, K., Sorvari, S., Antoniades, D., Brooks, S.J., Fallu, M.-A., Hughes, M., Keatley, B., Laing, T., Michelutti, N., Nazarova, L., Nyman, M., Paterson, A.M., Perren, B., Quinlan, R., Rautio, M., Saulnier-Talbot, É., Siitonen, S., Solovieva, N., Weckström, J., 2005. Climate-driven regime shifts in the biological communities of arctic lakes. Proceedings of the National Academy of Sciences of the United States of America 102, 4397-4402.

Solomina, O., Wiles, G., Arrigo, R., 2007. Multiproxy records of climate variability for Kamchatka for the past 400 years. Climate of the Past 3, 119-128.

Solovieva, N., Jones, V.J., Nazarova, L., Brooks, S.J., Birks, H.J.B., Grytnes, J.-A., Appleby, P.G., Kauppila, T., Kondratenok, B., Renberg, I., Ponomarev, V., 2005. Palaeolimnological evidence for recent climate change in lakes from the Northern Urals, Russia. Journal of Palaeolimnology 33, 463-482.

Stief, P., Nazarova, L., De Beer, D., 2005. Chimney construction by Chironomus riparius larvae in responce to hypoxia: microbal implications for freshwater sediments. Journal of North American Benthological Society 24, 858-871.

Taira, K., 1980. Environmental changes in eastern Asia during the past 2000 years. Volcanism, tectonism, climate and palaeooceanology. Palaeogeography, Palaeoclimatology, Palaeoecology 32, 89-97.

Taira, K., Lutaenko, K., 1993. Holocene palaeoceanographic changes in the Sea of Japan. Report of the Taisetsuzan Institute of Science 28, 65-70.

ter Braak, C.J.F., 1995. Ordination. In: Jongman, R. (Ed.), Data Analysis in Community and Landscape Ecology. Cambridge University Press, Cambridge, pp. 91-173.

ter Braak, C.J.F., Šmilauer, P., 2002. CANOCO for Windows: Software for Community Ordination (version 4.5). Microcomputer Power, Ithaca New York.

Velichko, A.A. (Ed.), 2010. Climates and Landscapes of Northern Eurasia Under Conditions of Global Warming. Retrospective Analysis and Scenarios (in Russian).

Walker, I.R., Fernando, C.H., Paterson, C.G., 1985. Association of Chironomidae (Diptera) of shallow, acid, humic lakes and bog pools in Atlantic Canada, and a comparison with an earlier paleological investigation. Hydrobiologia 120, 11-22. 
Walker, I.R., Mathewes, R.W., 1989. Early postglacial chironomid succession in southwestern British Columbia, Canada, and its paleaoenvironmental significance. Journal of Paleolimnology 2, 1-14.

Wetzel, R.G., 2001. Limnology: Lake and River Ecosystems. Academic Press, San Diego and London.

Wiederholm, T., 1983. Chironomidae of the Holarctic region. Keys and diagnoses. Part 1. Larvae. Entomologica Scandinavica (Suppl. 19).
Yasuda, Y., 1995. Climatic changes and the development of Jomon Culture in Japan. In: Nature and Humankind in the Age of Environmental Crisis. Proceedings of the VIth International Symposium at the International Research Center for Japanese Studies, pp. 57-77.

Zech, W., Bäumler, R., Savoskul, O., Braitseva, O.A., Melekesteve, J., 1997. Evidence of middle Pleistocene glaciation in SW-Kamchatka. Zeitschrift für Gletscherkunde und Glazialgeologie 33, 15-20. 